\title{
Assessing the functionality of viral entry-associated domains of porcine reproductive and respiratory syndrome virus during inactivation procedures, a potential tool to optimize inactivated vaccines
}

\author{
Iris Delrue, Peter L. Delputte, Hans J. Nauwynck* \\ Department of Virology, Parasitology and Immunology, Faculty of Veterinary Medicine, Ghent University, \\ Salisburylaan 133, 9820 Merelbeke, Belgium
}

(Received 16 January 2009; accepted 11 August 2009)

\begin{abstract}
Porcine reproductive and respiratory syndrome virus (PRRSV) causes severe economic losses in the pig industry worldwide. Currently, vaccines based on inactivated PRRSV provide limited protection of pigs against infection, most likely because viral epitopes associated with the induction of neutralizing antibodies are not or poorly conserved during inactivation. To analyze the effect of inactivation procedures on the interaction of PRRSV with receptors involved in virus entry, a new assay was set up in this study. Viral entry-associated domains are most likely important for the induction of neutralizing antibodies, since neutralizing antibodies block interaction of PRRSV with cellular receptors. To investigate the interaction of PRRSV with the cellular receptors upon different inactivation procedures, attachment to and internalization of inactivated PRRSV into macrophages were monitored. AT-2 could not inactivate PRRSV completely and is therefore not useful for vaccine development. PRRSV inactivated with ultraviolet light, binary ethyleneimine and gamma irradiation, which all mainly have an effect at the genomic level, showed no difference compared to control live virus at all levels of virus entry, whereas PRRSV treated with formaldehyde, glutaraldehyde and $\mathrm{pH}$ changes, which all have a modifying effect on proteins, was not able to internalize into macrophages anymore. These results suggest that inactivation with methods with a main effect on the viral genome preserve PRRSV entry-associated domains and are useful for future development of an effective inactivated vaccine against PRRSV. Although PRRSV incubation at $37^{\circ} \mathrm{C}$ can completely inactivate PRRSV with preservation of entry-associated domains, this method is not recommended for vaccine development, since the mechanism is yet unknown.
\end{abstract}

PRRSV / inactivation / vaccine / entry-associated domain / sialoadhesin

\section{INTRODUCTION}

Porcine reproductive and respiratory syndrome virus (PRRSV) is a single-stranded enveloped RNA virus which is assigned to the family Arteriviridae [11, 26, 37], together with lactate dehydrogenase-elevating virus

\footnotetext{
* Corresponding author: hans.nauwynck@ugent.be
}

(LDV), equine arteritis virus (EAV), and simian hemorrhagic fever virus (SHFV). The Arteriviridae as well as the Coronaviridae and Roniviridae belong to the order Nidovirales $[6,12,26]$.

PRRS is worldwide recognized as the economic most important viral pig disease [44]. Infection of pregnant sows may result in mummified and weak-born piglets, elevated preweaning mortality and abortion [9, 35, 59].

This is an Open Access article distributed under the terms of the Creative Commons Attribution-Noncommercial License (http://creativecommons.org/licenses/by-nc/3.0/), which permits unrestricted use, distribution, and reproduction in any noncommercial medium, provided the original work is properly cited. 
Infected boars may show a temporary decrease of sperm quality and virus shedding via sperm [51]. This virus shedding may lead to virus transmission to sows. Besides its effect on reproduction, PRRSV is also involved in the multifactorial respiratory disease complex in pigs, where the virus facilitates secondary bacterial infections and respiratory problems in pigs of all ages [55, 59].

Two main types of vaccines are currently used to prevent PRRSV infection, modified live virus (MLV) vaccines and killed virus (KV) vaccines [34, 68]. Commercial MLV and KV vaccines exist, but both have some disadvantages. MLV vaccines induce an immune response that can protect pigs against PRRSV infection, however only when the virus is not too distant from the vaccine strain [28, 29]. Attenuated viruses may cause safety problems. Some MLV vaccines may spread transplacentally $[18,36,46]$, be shed via semen and reduce semen quality $[10,47]$, and may even revert to virulence [45]. KV vaccines are safe to use, but currently used $\mathrm{KV}$ vaccines insufficiently protect pigs against viremia upon challenge, since both magnitude and duration of viremia were not different between vaccinated and control animals [68]. A comparative study of MLV and $\mathrm{KV}$ vaccines in boars showed that while vaccination with an MLV vaccine decreased viremia and virus shedding in semen, vaccination with a KV vaccine did not change onset, duration or level of viremia, or virus shedding in semen [47]. Preliminary experiments in our lab showed that while an experimental inactivated PRRSV vaccine was able to induce neutralizing antibodies, it could only partly block viremia after challenge [41]. The current incomplete protection of KV vaccines against PRRSV infection might be caused by an over-inactivation of the virus, resulting in destruction of neutralizing viral epitopes. Neutralizing viral epitopes induce the production of neutralizing antibodies by the host, which are necessary for neutralization of the virus and reduction of overall infection. As a result, destruction of the neutralizing epitopes by over-inactivation will reduce the number of neutralizing antibodies raised by the host, which will ultimately lead to less efficient protection against a viral challenge.

To our knowledge, currently used KV vaccines against PRRSV have been evaluated for the quantity of viral antigens, but not the quality. For other viruses, the quality has been examined. For example, the effect of inactivation of influenza virus is investigated by measuring the hemagglutinating activity before and after inactivation [19]. For HIV, the attachment of neutralizing antibodies to viral epitopes is determined after inactivation by an enzymelinked immuno sorbent assay (ELISA) [25, 50]. ELISA as a tool for quality control of the antigen is also used for rabies virus [21, 53] and poliovirus vaccines [43]. Quality control for PRRSV cannot be performed using the same methods as for HIV and influenza, because of the limited knowledge of PRRSV neutralizing epitopes. There are some neutralizing epitopes known on GP5 and GP4 [39, 48, $66]$ and there are possibly also neutralizing epitopes on GP3 [5], but it is not known if other important epitopes exist and which neutralizing epitopes are most important. Previous results from our lab showed that PRRSV neutralizing antibodies block infection by preventing the interaction of PRRSV with the internalization receptor sialoadhesin $(\mathrm{Sn})$ on the target cells, macrophages [15, 16, 60, 61]. This indicates that neutralizing antibodies are directed to the viral epitopes that are involved in the attachment to the PRRSV receptors and internalization into the macrophage [15]. Based on this observation, a quality control of the viral antigen of a PRRSV KV vaccine was developed, by monitoring PRRSV attachment to and internalization into macrophages before and after inactivation. An ideal killed PRRSV vaccine should be able to attach to and internalize into macrophages during a quality-control assay, but it should be disabled to replicate in order to avoid viremia.

The aim of this study is to investigate the effect of different PRRSV inactivation methods on the viral entry-associated domains. To this end, inactivated PRRSV attachment to and internalization into macrophages were monitored. 


\section{MATERIALS AND METHODS}

\subsection{Cells and virus}

The European PRRSV strain, Lelystad virus (LV) [63], grown on Marc-145 cells (4th passage) was used for inactivation. Marc-145 cells cultivated in minimum Eagle's medium (MEM) with 5\% fetal bovine serum (FBS), $0.3 \mathrm{mg} / \mathrm{mL}$ glutamine, $100 \mathrm{U} / \mathrm{mL}$ penicillin, $0.1 \mathrm{mg} / \mathrm{mL}$ streptomycin and $0.1 \mathrm{mg} / \mathrm{mL}$ kanamycin were used for LV production and titration. Virus attachment and internalization were investigated in macrophages cultivated in RPMI 1640 with $10 \%$ FBS, $100 \mathrm{U} / \mathrm{mL}$ penicillin, $0.1 \mathrm{mg} / \mathrm{mL}$ streptomycin, $0.1 \mathrm{mg} / \mathrm{mL}$ kanamycin, $0.1 \mathrm{mg} / \mathrm{mL}$ gentamycin, $0.01 \mathrm{mg} / \mathrm{mL}$ tylosin, $0.3 \mathrm{mg} / \mathrm{mL}$ glutamine, $1 \mathrm{mM}$ nonessential amino acids and $1 \%$ sodium pyruvate $(100 \times)$ for $24 \mathrm{~h}$.

\subsection{PRRSV concentration and purification}

The European PRRSV strain, LV, was grown on Marc-145 cells. The medium containing the virus was purified as described by Delputte et al. [15], this with some modifications to allow purification of larger quantities of virus. Virus supernatant was first filtrated through a $0.45 \mu \mathrm{m}$ filter and then ultracentrifuged for $2 \mathrm{~h}$ at $31000 \mathrm{rpm}$ with a rotor type 35 at $4{ }^{\circ} \mathrm{C}$ (Beckmann Coulter, Analis, Ghent, Belgium) to pellet the virus. The resuspended virus pellet was centrifuged $10 \mathrm{~min}$ at $13000 \mathrm{rpm}$ (Heraeus fresco, Thermo Fisher Scientific, Zellik, Belgium) to remove cell debris and large aggregates and the supernatant was ultra-centrifuged through a $30 \%$ sucrose cushion for $3 \mathrm{~h}$ at $30000 \mathrm{rpm}$ with a SW 41 Ti rotor at $4{ }^{\circ} \mathrm{C}$ (Beckmann Coulter). Finally, the virus pellet was resuspended in $1 \mathrm{~mL}$ PBS by incubating it for $1 \mathrm{~h}$ on ice.

\subsection{Inactivation methods}

An overview of the inactivation methods used and their mode of action is shown in Table I. Purified virus $\left(10^{7} \mathrm{TCID}_{50} / \mathrm{mL}\right)$ was used for inactivation. For inactivation with formaldehyde, glutaraldehyde or 2,2-dithiodipyridine (AT-2), virus was incubated for $4 \mathrm{~h}$ at $37^{\circ} \mathrm{C}$ with different concentrations formaldehyde (Sigma, Bornem, Belgium) [14, 54], glutaraldehyde (Sigma) [14] or AT-2 (Aldrich, Bornem, Belgium) [7, 54]. Formaldehyde, glutaraldehyde or AT-2 was afterwards removed by ultracentrifugation. For inactivation by changing the $\mathrm{pH}$, the $\mathrm{pH}$ was adjusted with $\mathrm{HCl}$ and $\mathrm{NaOH}$ and virus was incubated for different times at a $\mathrm{pH} 2$ or at a $\mathrm{pH} 12$. After incubation, the $\mathrm{pH}$ was neutralized [14]. For temperature inactivation, virus was incubated for different times at $37{ }^{\circ} \mathrm{C}[14,33]$. Inactivation of PRRSV with gamma irradiation was performed using an electron accelerator (Prof. L. Van Hoorebeke, Ghent University, Faculty of Science, Department of Subatomic and Radiation Physics). For PRRSV inactivation with ultraviolet (UV) radiation, virus was radiated with UV light from a UV cross-linker (BRS, Drogenbos, Belgium) [14]. Inactivation with binary ethyleneimine (BEI) was performed by incubating virus with $1 \mathrm{mM}$ BEI (Aldrich) for different times at $37{ }^{\circ} \mathrm{C}$. The reaction was stopped with $0.1 \mathrm{mM}$ sodium thiosulfate (Sigma) [2, 42].

\subsection{Analysis of virus inactivation}

Virus titration was performed on 3 days cultivated Marc-145 cells following the standard procedure [3]. After 5 days, occurrence of cytopathic effect (CPE) was investigated and the $50 \%$ tissue culture infective dose $\left(\mathrm{TCID}_{50}\right)$ was calculated.

To confirm that all virus was completely inactivated using selected inactivation procedures, either a complete dose $\left(10^{7} \mathrm{TCID}_{50} / \mathrm{mL}\right.$ virus $)$ or $10 \times$ more virus was inactivated and used for inoculation of Marc-145 cells, followed by two blind passages. The Marc-145 cells were investigated every week for $\mathrm{CPE}$ and cells were stained by immunoperoxidase monolayer assay (IPMA) [30]. Additionally, a bioassay was also done for selected inactivation methods by injecting $10^{7} \mathrm{TCID}_{50} / \mathrm{mL}$ inactivated PRRSV in RPMI 1640 medium intramuscularly in a pig. Blood was taken every week and serum was checked for viremia by virus titration and PRRSV specific antibodies by IPMA up to 2 weeks post inoculation.

\subsection{Effect of PRRSV inactivation on virus attachment, internalization, disassembly and infection by immunofluorescence staining}

For the detection of PRRSV during the course of PRRSV infection, macrophages were inoculated with untreated or treated PRRSV (moi 2) for $1 \mathrm{~h}$ at $4{ }^{\circ} \mathrm{C}$ or 1,5 and $10 \mathrm{~h}$ at $37^{\circ} \mathrm{C}$, fixed with methanol at $-20{ }^{\circ} \mathrm{C}$ and stained as described by Delputte et al. [15]. Briefly, the capsid protein was stained with a primary antibody P3/27 [64] and a secondary antibody fluorescein isothiocyanate (FITC)-conjugated goat polyclonal anti-mouse immunoglobulins (Molecular Probes, Invitrogen, Merelbeke, Belgium). 
Table I. Overview of the inactivation methods used to inactivate PRRSV.

\begin{tabular}{lcl}
\hline Method & \multicolumn{1}{c}{ Type } & \multicolumn{1}{c}{ Mechanism } \\
\hline Formaldehyde & Alkylating agent & Monohydroxy-methylizing of adenine [1] \\
Cross-linker & $\begin{array}{l}\text { Cross-linking of RNA to capsid proteins [20, 27, 32], } \\
\text { causing a block of genome reading [49] }\end{array}$ \\
& $\begin{array}{l}\text { Cross-linking of proteins by formation of inter- and intramolecular } \\
\text { methylene bridges between hydroxymethylated amines [22] }\end{array}$
\end{tabular}

Glutaraldehyde Cross-linker Cross-linking of proteins by the same mechanism as formaldehyde described above [8]

AT-2 Cross-linker

Cross-linking of proteins by oxidation of S-H groups causing formation of S-S bridges which results in a covalent modification and functional inactivation of S-H-containing internal viral proteins [7]

$\mathrm{pH} \quad$ Denaturation agent

Denaturation of proteins, the conformation of spike proteins of coronaviruses for example enables fusion of the virus with the host cell by changes to a $\mathrm{pH}$ of 8 [62]

Temperature Denaturation agent A high temperature denaturates proteins. As a result, the conformation of viral proteins that are involved in attachment and replication in a host cell may have changed $[31,56]$

Gamma irradiation Radiation

Viruses are inactivated primarily by direct damage, via disruption of the genome [24]

Formation of free radicals which damage proteins [24]

UV light Radiation Induction of dimer formation between adjacent uracils in RNA [40,57]. Dimer formation leads to pressure and breakage of the sugar backbone causing a block of genome reading More slowly, UV also causes structural modifications of the capsid proteins resulting in the formation of large and small photoproducts [40, 58]

BEI Alkylating agent

Alkylation of RNA at low concentrations. Most likely genome reading is blocked by alkylation of guanine or adenine by BEI [4, 23] Alkylation of proteins (nucleocapsid) at high concentrations [4]

A virus stock with a ratio of $1 / 100$ of infectious virus/ non-infectious virus was used for inoculation. This is determined by application of diluted samples of virus suspension to glass slides, fixed with methanol and stained against nucleocapsid as described above. This showed that the virus stock with $10^{6} \mathrm{TCID}_{50} / \mathrm{mL}$ contained approximately $10^{8}$ particles $/ \mathrm{mL}$. Confocal analysis was performed using a TCS SP2 laser scanning spectrum confocal system (Leica Microsystems $\mathrm{GmbH}$, Heidelberg, Germany) to determine the amount of internalized PRRSV. The numbers of bound and internalized PRRSV were counted from the acquired images. The amount of internalized PRRSV of both treated and untreated virus in a macrophage were determined by counting the small fluorescently labeled dots and set relatively to internalized untreated virus.

\subsection{Inhibition of phagocytosis}

Macrophages were pre-treated for $30 \mathrm{~min}$ with $0.1 \mu \mathrm{M}$ wortmannin to block phagocytosis. Afterwards the macrophages were inoculated with untreated or treated virus for $1 \mathrm{~h}$ at $37{ }^{\circ} \mathrm{C}$ in the presence of $0.1 \mu \mathrm{M}$ wortmannin. Then the cells were fixed with methanol at $-20{ }^{\circ} \mathrm{C}$ and stained as described by Delputte et al. [15]. Briefly, the capsid protein was stained with a primary antibody $\mathrm{P} 3 / 27$ [64] and a secondary antibody FITC-conjugated goat 
polyclonal anti-mouse immunoglobulins (Molecular Probes, Invitrogen). Confocal analysis was performed to check for endocytosis.

\subsection{Analysis of the viral proteins of inactivated PRRSV by SDS-PAGE and Western blotting}

SDS-PAGE, Western Blotting and ECL of viral proteins were performed essentially as described by Delputte et al. [17]. The membranes were stained for $1 \mathrm{~h}$ with a primary mouse monoclonal antibody against one of the proteins of LV, M (126.3) [38], $\mathrm{N}(\mathrm{P} 3 / 27)$ [64], GP5 (4BE12) [52], GP4 (122.29) [39], GP3 (P9A3-20) (Intervet, Boxmeer, the Netherlands) or pig polyclonal antibody.

\section{Results}

\subsection{Effect of different treatments on PRRSV infectivity}

To test the potential of the different PRRSV inactivation treatments, purified virus $\left(10^{7}\right.$ $\mathrm{TCID}_{50} / \mathrm{mL}$ ) was treated with formaldehyde, glutaraldehyde, AT-2, $\mathrm{pH}, 37{ }^{\circ} \mathrm{C}$, gamma irradiation, UV light or BEI, using different concentrations, time periods and/or doses. Treated PRRSV was titrated to determine an inactivation curve (Fig. 1). There was no infectious virus detected when PRRSV was treated with the lowest concentration of formaldehyde $(0.1 \mu \mathrm{g} / \mathrm{mL})$ (Fig. 1A), the lowest gamma irradiation dose $(0.25 \mathrm{kGy})$ (Fig. 1F), the lowest UV irradiation dose $\left(100 \mathrm{~mJ} / \mathrm{cm}^{2}\right)$ (Fig. 1G), or at the first time point investigated for inactivation with pH2 (1 h) (Fig. 1D), pH12 (data not shown), and BEI $(6 \mathrm{~h})$ (Fig. 1H). For glutaraldehyde, the amount of infectious virus decreased in function of the concentration and no infectious virus could be detected upon incubation with a concentration of $0.5 \mu \mathrm{g} / \mathrm{mL}$ glutaraldehyde or more (Fig. 1B). PRRSV was still infectious after $4 \mathrm{~h}$ incubation at $37{ }^{\circ} \mathrm{C}$ with the highest concentration of $2 \mathrm{mM}$ AT-2 (Fig. 1C). For $37^{\circ} \mathrm{C}$ treatment, the amount of infectious virus decreased in a time dependent way and there was no infectious virus detected after $48 \mathrm{~h}$ incubation at
$37{ }^{\circ} \mathrm{C}$ (Fig. 1E). For formaldehyde, glutaraldehyde and AT-2, the titer at time point 0 was lower than $10^{7} \mathrm{TCID}_{50} / \mathrm{mL}$, because of loss of some virus during ultracentrifugation. These results showed that for all inactivation methods, except for AT-2, a minimal treatment that allowed complete virus inactivation could be determined.

\subsection{Effect of different inactivation procedures on virus internalization into macrophages}

To investigate the preservation of the entryassociated domains of the treated PRRSV, an immunofluorescence staining was performed to determine whether internalization of inactivated PRRSV into macrophages was still possible. The results of these internalization experiments are shown in Figures 2 and 3. PRRSV inactivated with $1 \mu \mathrm{g} / \mathrm{mL}$ formaldehyde (Figs. 2A and 3), $50 \mu \mathrm{g} / \mathrm{mL}$ glutaraldehyde (Figs. 2B and 3), pH2 (Figs. 2D and 3) or $\mathrm{pH} 12$ (data not shown) for $1 \mathrm{~h}$ was no longer able to internalize into macrophages. The internalization experiments with AT-2 inactivated PRRSV (Figs. 2C and 3) showed that PRRSV treated with all concentrations of AT-2 tested, could still internalize into macrophages, but this was to be expected since the virus was still infectious even at the highest concentration of AT-2. The internalization experiments for $37^{\circ} \mathrm{C}$ and BEI inactivation (Figs. 2E, 2H and 3) showed that PRRSV incubated at $37^{\circ} \mathrm{C}$ or treated with $1 \mathrm{mM}$ BEI could still internalize into macrophages for all time points investigated. PRRSV treated with all doses of gamma irradiation or UV examined could still internalize into macrophages, but the internalization diminished in a dose dependent way for gamma irradiation inactivated PRRSV (Figs. 2F, 2G and 3).

Together, these data show that the entryassociated domains were not preserved when PRRSV is inactivated with formaldehyde, glutaraldehyde or $\mathrm{pH}$ changes, while they were preserved using AT-2, $37^{\circ} \mathrm{C}$, gamma irradiation, UV or BEI. About $20 \%$ of the cells inoculated with PRRSV inactivated with methods 

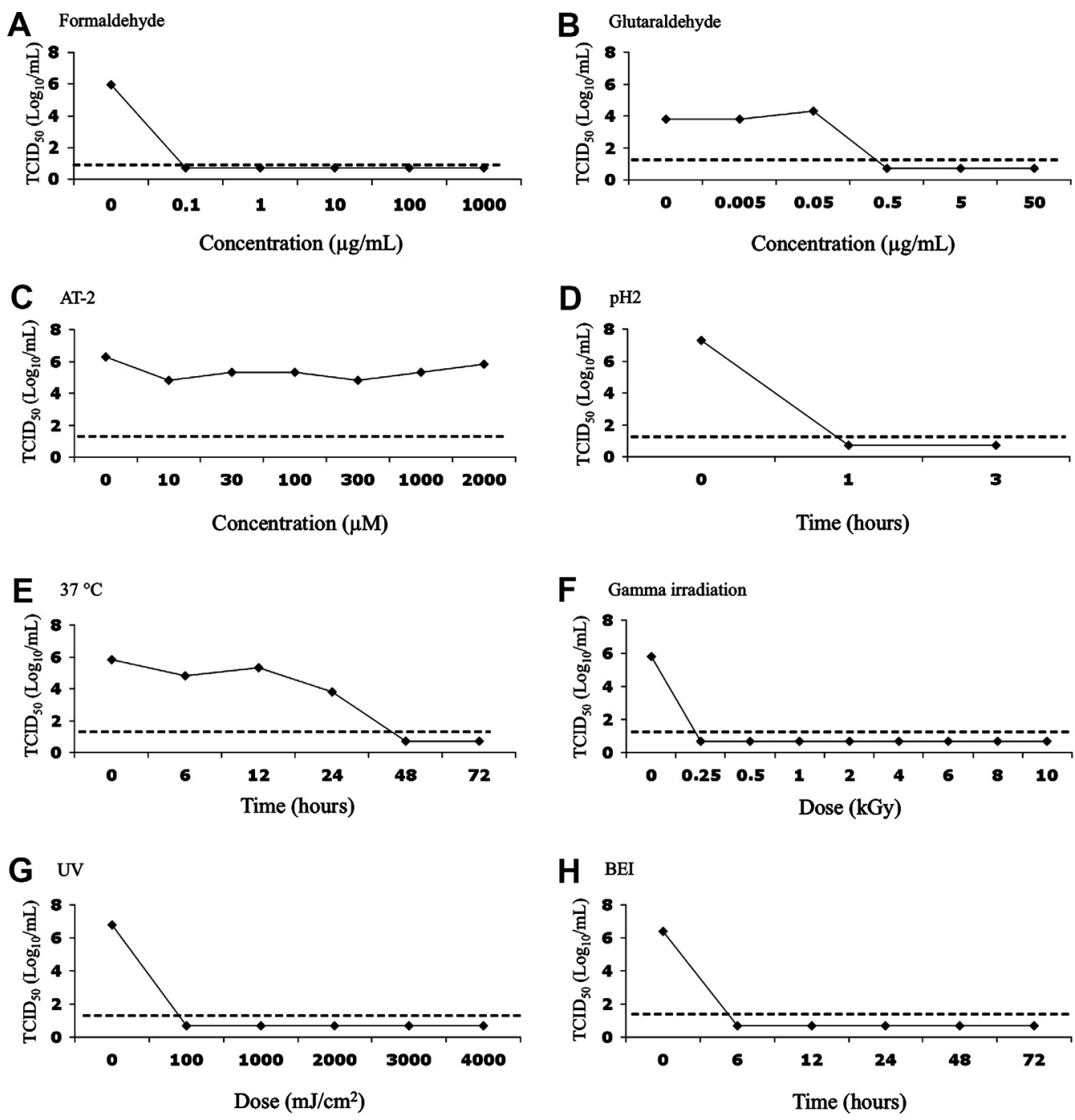

Figure 1. Effect of different inactivation methods on PRRSV infectivity. Untreated LV or inactivated LV was titrated on 3 days cultured Marc-145 cells to determine presence of infectious virus in the samples. The dotted line resembles the detection limit of the assay.

that still allowed internalization, showed internalization, because untreated PRRSV infects only about $20 \%$ of the macrophages in vitro. From the cells inoculated with PRRSV inactivated with methods that did not allow internalization anymore, there were no cells that showed internalization at all.
3.3. Effect of the different inactivation methods on different stages in the virus replication cycle in macrophages

PRRSV inactivated with formaldehyde, glutaraldehyde and $\mathrm{pH}$ changes was not able to internalize into macrophages, which is a 

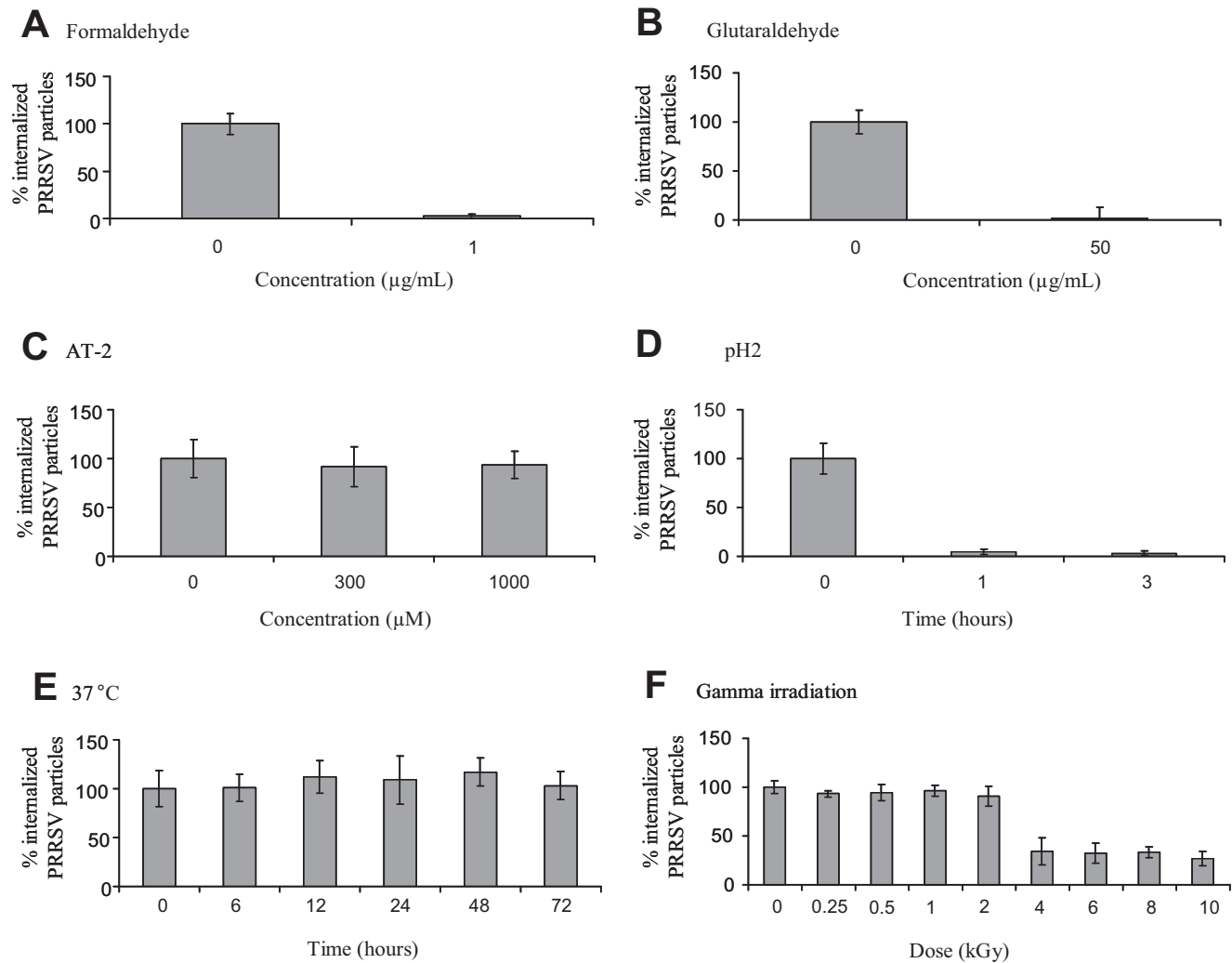

F Gamma irradiation
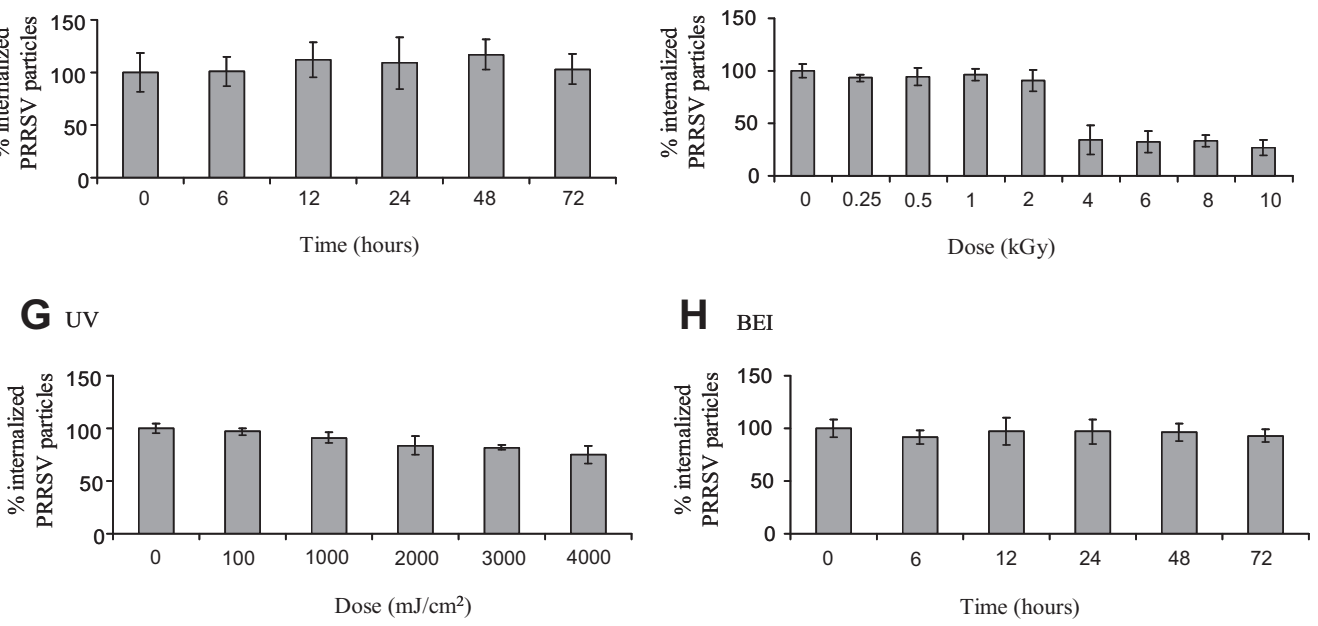

Figure 2. Effect of different inactivation methods on PRRSV internalization. Macrophages were incubated with untreated LV or inactivated LV for $1 \mathrm{~h}$. After $1 \mathrm{hpi}$, the virus was stained by immunofluorescence and internalization of PRRSV particles was determined by confocal microscopy. The amount of internalized PRRSV particles of both treated and untreated virus in a macrophage were counted by counting the small fluorescently labeled dots and set relatively to internalized untreated virus.

crucial step in the viral replication cycle. Because internalization did not occur, the uncoating, virus replication, assembly and release did also not occur (Fig. 3).
PRRSV inactivated by $37{ }^{\circ} \mathrm{C}$, gamma irradiation, UV and BEI could still internalize into macrophages, thus it was able to perform this step of the viral replication cycle. After 


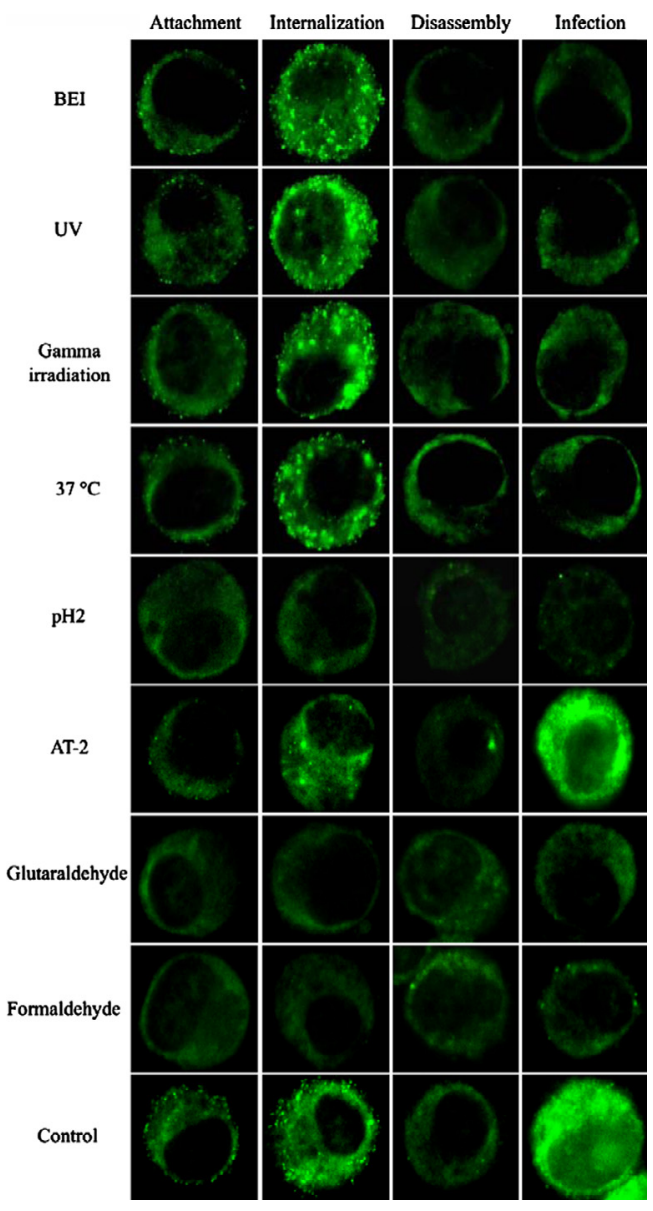

Figure 3. Effect of different inactivation methods on different stages of the viral replication cycle. Macrophages were incubated with inactivated LV or untreated $\mathrm{LV}$ for $1 \mathrm{~h}$ at $4{ }^{\circ} \mathrm{C}$ and 1,5 or $10 \mathrm{~h}$ at $37{ }^{\circ} \mathrm{C}$. After fixing and immunofluorescence staining of the cells, attachment $\left(1 \mathrm{hpi}\right.$ at $\left.4{ }^{\circ} \mathrm{C}\right)$, internalization ( 1 hpi at $\left.37^{\circ} \mathrm{C}\right)$, disassembly $(5 \mathrm{hpi}$ at $37^{\circ} \mathrm{C}$ ) and replication $\left(10 \mathrm{hpi}\right.$ at $\left.37^{\circ} \mathrm{C}\right)$ was analyzed by confocal microscopy.

$5 \mathrm{~h}$, the uncoating occurred, thus also the second step of the viral replication cycle could be performed. The inactivated virus was however not capable of replicating and this thus confirmed the completely inactivated status of the virus (Fig. 3).

\subsection{Inhibition of phagocytosis to confirm receptor-mediated endocytosis after inactivation}

To investigate if entry of the inactivated PRRSV in macrophages occurred via $\mathrm{Sn}$ and CD163 as described for infectious PRRSV $[60,61]$, and not simply taken up by phagocytosis, entry was also determined using a phagocytosis inhibitor wortmannin. After treatment of the macrophages with the phagocytosis inhibitor wortmannin, untreated PRRSV still attached to and internalized into macrophages. PRRSV inactivated with UV and BEI also attached to and internalized into macrophages, whereas formaldehyde and glutaraldehyde inactivated PRRSV could not attach and internalize.

\subsection{Safety test to confirm complete inactivation}

Gamma irradiation, UV and BEI seemed to be useful methods for killed PRRSV vaccine development, since the inactivated virus attaches and enters macrophages in a similar way as the virulent virus. Therefore, safety tests were done to confirm that the inactivated virus was completely inactivated and safe for use in pigs. First, $10^{7}$ TCID $_{50} / \mathrm{mL}$ virus was inactivated and Marc-145 cells were inoculated for two passages with the inactivated virus. This test indicated that virus inactivated with $0.25 \mathrm{kGy}$ gamma irradiation, $100 \mathrm{~mJ} / \mathrm{cm}^{2}$ UV or $6 \mathrm{~h}$ incubation with BEI were completely inactivated (data not shown). To be sure the virus was inactivated, $1.5 \mathrm{kGy}$ gamma irradiation, $1000 \mathrm{~mJ} / \mathrm{cm}^{2} \mathrm{UV}$ or $24 \mathrm{~h}$ incubation with BEI were selected as a safe method to inactivate PRRSV. A second test was performed by inactivating a higher concentrated virus suspension under the same conditions $\left(10^{8} \mathrm{TCID}_{50} / \mathrm{mL}\right.$ virus $)$. The results demonstrated that $1000 \mathrm{~mJ} / \mathrm{cm}^{2} \mathrm{UV}$ or $24 \mathrm{~h}$ incubation with BEI could still completely inactivate 10 times more virus (data not shown). Virus $\left(10^{8} \mathrm{TCID}_{50} / \mathrm{mL}\right.$ virus $)$ inactivated with gamma irradiation was not completely inactivated with a dose of $1.5 \mathrm{kGy}$ and starting from a dose of $2 \mathrm{kGy}$, the preservation of 
entry-associated domains decreases. Therefore, inactivation with gamma irradiation is not useful for further vaccine development. Finally, to confirm complete inactivation, a bioassay was performed. Therefore, $10^{7} \mathrm{TCID}_{50} / \mathrm{mL}$ virus was inactivated with $1000 \mathrm{~mJ} / \mathrm{cm}^{2} \mathrm{UV}$ or $24 \mathrm{~h}$ incubation with BEI and intramuscularly injected in pigs. Viremia was not detected up to 2 weeks after injection, while virus specific antibodies were induced, which suggests that the virus was completely inactivated and safe to use in pigs (data not shown).

\subsection{Western blot analysis of the viral proteins of inactivated PRRSV}

The effect of different inactivation methods on viral proteins was further investigated by analyzing the protein pattern of the virus before and after inactivation by Western blotting (Fig. 4, Tab. II). Under reducing as well as under non-reducing circumstances, all the viral proteins were present after inactivation with formaldehyde, AT-2 and gamma irradiation, but to a lesser extent as untreated PRRSV. For glutaraldehyde, under reducing as well as under non-reducing conditions not all the viral proteins could be detected after inactivation. The protein pattern of the virus before and after inactivation by UV irradiation was not identical, which suggests that UV irradiation resulted in the degradation of the viral proteins. For $\mathrm{pH}$ changes, $37^{\circ} \mathrm{C}$ and BEI all the viral proteins were present after inactivation. Complexes like N-dimer and M-GP5 however were more degraded in comparison to the untreated virus when treated with $\mathrm{pH}$ changes.

The formaldehyde, glutaraldehyde, $\mathrm{pH}$, AT-2, gamma irradiation and UV inactivated PRRSV did not have the same protein pattern as the untreated virus. These results indicated that with these inactivation procedures inactivated PRRSV did not resemble infectious PRRSV. The $37^{\circ} \mathrm{C}$ and BEI inactivated PRRSV showed the same protein pattern as the untreated virus. These results suggest that PRRSV inactivated at $37{ }^{\circ} \mathrm{C}$ or by BEI resembles infectious PRRSV.

\section{DISCUSSION}

Virus inactivation procedures with the aim to develop inactivated virus vaccines should have two major goals: complete inactivation of infectious virus (safety), while conserving epitopes of the inactivated virus that are important for the induction of protective immunity (antigen quality). This study aimed to test different inactivation procedures for PRRSV to evaluate the effect on both reduction of infectivity and conservation of viral entry-associated domains, the latter being a measure for the quality of the antigen used.

Currently, there are no data available in literature on inactivation procedures of PRRSV. Therefore, inactivation methods and conditions used in this study are based on studies where inactivation of other viruses was evaluated. Evaluation of the capacity of different inactivation procedures to completely inactivate PRRSV showed similarities and differences with that of other viruses. PRRSV could not be inactivated with AT-2, not even after treatment with $2 \mathrm{mM}$ for $4 \mathrm{~h}$ at $37^{\circ} \mathrm{C}$, while HIV type 1 is already inactivated with $100 \mu \mathrm{M}$ AT-2 after $1 \mathrm{~h}$ at $37{ }^{\circ} \mathrm{C}$ [54]. AT-2 modifies free thiol groups of internal viral proteins like the nucleocapsid of HIV-1, more specifically zincfinger motifs important for HIV-1 infection, leaving disulfide bridges of glycoproteins in the virus envelope unaffected [7, 65], but for PRRSV the formation of homodimers of nucleocapsid proteins via disulfide bridges is important for virus infection [67]. Since PRRSV seems not to be sensitive for AT-2, this product cannot be used to develop an inactivated PRRSV vaccine. For PRRSV inactivation with formaldehyde and glutaraldehyde, respectively 0.1 and $0.5 \mu \mathrm{g} / \mathrm{mL}$ for $4 \mathrm{~h}$ at $37^{\circ} \mathrm{C}$ was sufficient. In comparison, HIV-1 can be inactivated with $2 \mu \mathrm{g} / \mathrm{mL}$ formaldehyde after $24 \mathrm{~h}$ at $37^{\circ} \mathrm{C}$ [54] and SARS-CoV with $90 \mu \mathrm{g} / \mathrm{mL}$ formaldehyde or $20 \mu \mathrm{g} / \mathrm{mL}$ glutaraldehyde after $24 \mathrm{~h}$ at $37^{\circ} \mathrm{C}$ [14]. For PRRSV inactivation by changing the $\mathrm{pH}$, incubation of the virus at a $\mathrm{pH} 2$ or $\mathrm{pH} 12$ for $1 \mathrm{~h}$ at $37^{\circ} \mathrm{C}$ was effective. Also SARS-CoV could be inactivated after incubation of $1 \mathrm{~h}$ at $37^{\circ} \mathrm{C}$ at a $\mathrm{pH} 2$ or $\mathrm{pH} 12$ 


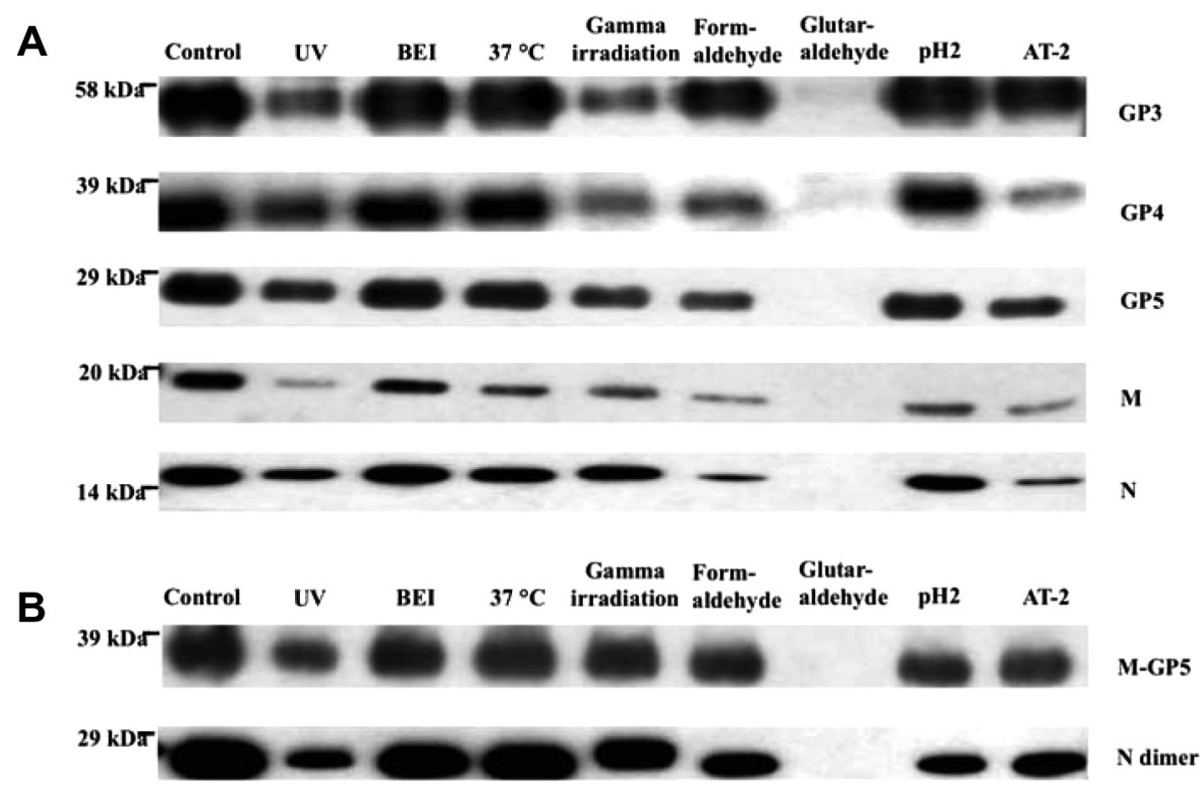

Figure 4. Effect of different inactivation methods on PRRSV proteins. Western blot analysis of untreated LV or inactivated LV in reducing (A) and non-reducing (B) conditions.

Table II. Density of Western blots.

\begin{tabular}{lccccccccc}
\hline & Control & $\mathrm{UV}$ & $\mathrm{BEI}$ & $37^{\circ} \mathrm{C}$ & Gamma irradiation & Formaldehyde & Glutaraldehyde & AT-2 & $\mathrm{pH} 2$ \\
\hline $\mathrm{N}$ & 100 & 48 & 103 & 85 & 83 & 30 & 6 & 26 & 82 \\
$\mathrm{M}$ & 100 & 14 & 65 & 46 & 48 & 23 & 6 & 23 & 40 \\
$\mathrm{GP5}$ & 100 & 56 & 95 & 87 & 56 & 42 & 1 & 50 & 75 \\
GP4 & 100 & 73 & 93 & 91 & 50 & 50 & 13 & 28 & 83 \\
GP3 & 100 & 47 & 94 & 95 & 39 & 83 & 5 & 83 & 94 \\
$\mathrm{~N}$ dimer & 100 & 45 & 83 & 92 & 66 & 43 & 0 & 43 & 31 \\
M-GP5 & 100 & 58 & 87 & 92 & 80 & 73 & 0 & 63 & 67 \\
\hline
\end{tabular}

[14]. Incubation of PRRSV for $48 \mathrm{~h}$ at $37^{\circ} \mathrm{C}$ was efficient for its inactivation, while SARS$\mathrm{CoV}$ was inactivated after incubation of $20 \mathrm{~min}$ at $56{ }^{\circ} \mathrm{C}$ [14] and adenovirus type 5 after $10 \mathrm{~min}$ at $50{ }^{\circ} \mathrm{C}$ [33]. For this study, inactivation of PRRSV at higher temperatures was not considered, since PRRSV proteins, similar to what is observed with other viruses [56], will most likely be denaturated, thereby destroying important epitopes. PRRSV inactivation with gamma irradiation or UV could be achieved with an irradiation dose of respectively $0.25 \mathrm{kGy}$ or $100 \mathrm{~mJ} / \mathrm{cm}^{2}$. SARS-CoV could not be inactivated with gamma irradiation, even not after an irradiation dose of $15000 \mathrm{rad}$. For inactivation with $\mathrm{UV}$, an irradiation dose of $3614 \mathrm{~mJ} / \mathrm{cm}^{2}$ was needed [14]. BEI inactivation of PRRSV could be achieved with $1 \mathrm{mM}$ BEI after $6 \mathrm{~h}$ incubation at $37^{\circ} \mathrm{C}$. Berhane et al. [2] inactivated Nipah virus with $3 \mathrm{mM}$ BEI for $24 \mathrm{~h}$ at room temperature and Mondal et al. [42] used $1.6 \mathrm{mM}$ BEI for $24 \mathrm{~h}$ at $37^{\circ} \mathrm{C}$ to inactivate rabies virus. In conclusion, for all tested inactivation procedures, except for AT-2, conditions that allowed PRRSV inactivation could be determined.

Besides inactivation, conservation of viral entry-associated domains is equally important 
for the development of an inactivated virus vaccine. An in vitro assay to check the conservation of viral domains that are important for the induction of a protective immunity is preferred to avoid time consuming vaccination studies and to allow precise fine tuning of inactivation methods. For influenza virus and HIV for example, the major neutralizing epitopes are known and an in vitro assay to analyze the conservation of these domains after inactivation can be performed by measuring haemagglutination for influenza virus [19] or by ELISA for HIV [25]. However, for PRRSV there is currently no in vitro assay to evaluate this due to a limited knowledge on the PRRSV neutralizing epitopes. In our lab, it was shown that neutralizing antibodies were preventing infection by disturbing entry of the virus into macrophages [15]. Therefore, it was hypothesized that viral domains important for viral entry (entryassociated domains) are also important for the induction of viral neutralizing antibodies. In this study, different inactivation methods for PRRSV were analyzed for their effect on the viral domains important for entry into macrophages, which are most likely also important for the induction of neutralizing antibodies. Our experiments with formaldehyde, glutaraldehyde and $\mathrm{pH}$ inactivated PRRSV suggest that the viral entry-associated domains are modified, since the virus can no longer attach to and internalize into macrophages. Similarly, Western blotting showed that the viral proteins were not or to a lesser extent present, which is probably due to cross-linking of proteins by formaldehyde and glutaraldehyde or denaturation of viral proteins by $\mathrm{pH}$ changes. Formaldehyde and glutaraldehyde are known to have a similar effect on proteins, as they are able to induce protein cross-linking $[1,8,22]$, while $\mathrm{pH}$ changes affect proteins by denaturation [62]. Cross-linking or denaturation of viral domains that are involved in attachment and internalization of PRRSV might interfere with the subsequent presentation of viral domains to cells of the adaptive immune system. As a result, inactivation with formaldehyde, glutaraldehyde and $\mathrm{pH}$ changes will probably give a poor preservation of viral immunogenicity $[13,54]$. In conclusion, formaldehyde, glutaraldehyde and $\mathrm{pH}$ changes are not effective methods to inactivate PRRSV with preservation of the entry-associated domains and for future vaccine development.

Because gamma irradiation mainly has an effect at the genomic level, one could assume that this would be an effective method to inactivate PRRSV. However, the range between complete inactivation and preservation of the entry-associated domains was too small to use this method in a safe way for vaccine development. PRRSV inactivated with a dose of $1.5 \mathrm{kGy}$ was still infectious, while PRRSV inactivated with a dose of $2 \mathrm{kGy}$ was no longer infectious, but could not efficiently internalize into macrophages. At this dose viral entry-associated domains are most likely destroyed due to the formation of free radicals which damage proteins [24]. This viral protein degradation was also seen on Western blot. In conclusion, gamma irradiation is not suitable as a method to inactivate PRRSV.

Temperature inactivation has been documented to inactivate viruses by denaturation $[31,56]$. As with protein cross-linking, denaturation of viral proteins may also destroy the entry-associated domains of PRRSV. However, a modest increase of temperature $\left(37^{\circ} \mathrm{C}\right)$ did not prevent PRRSV to attach to and internalize into macrophages, while preventing viral replication. Incubating PRRSV at $37^{\circ} \mathrm{C}$ would thus be an interesting option to generate a killed PRRSV vaccine. Clearly, inactivation at $37{ }^{\circ} \mathrm{C}$ does not result in denaturation of viral proteins. This is confirmed by Western blotting, since no difference was observed in the banding pattern between not inactivated control virus and inactivated virus. However, since the mechanism of inactivation is unknown, it might not be safe to use this method to inactivate PRRSV for vaccine development.

Of all methods tested, the most promising methods to inactivate PRRSV for KV vaccine development are UV and BEI, because they mainly have an effect on genomic level, preserving entry-associated viral domains. This was shown by internalization of the inactivated virus into macrophages. However, for UV the destruction of capsid proteins has been reported [40]. Western blot analysis in this study indeed 
showed degradation of viral proteins upon UV inactivation.

By investigating internalization into macrophages, the possibility exists that the inactivated virus is taken up by phagocytosis instead of using the PRRSV entry receptor Sn. However, PRRSV inactivated by UV and BEI did also attach to and internalized into macrophages after treatment with a phagocytosis inhibitor. These results confirm that inactivated PRRSV could still interact with PRRSV receptors and that thus internalization of BEI or UV inactivated PRRSV into macrophages did not occur via phagocytosis.

In summary, the results of this study show that inactivation methods that have a direct effect on viral proteins, like formaldehyde, glutaraldehyde and changing the $\mathrm{pH}$ are not good candidates for viral inactivation, as they do not conserve viral entry-associated domains. On the other hand, UV, BEI and gamma irradiation, which mainly have an effect on the genome, could be interesting methods to inactivate PRRSV for vaccine development, as inactivated virus is still able to internalize into macrophages, but no longer replicates. However, UV and gamma irradiation may give problems with photoproducts or free radicals formed during irradiation, which in turn could indirectly degrade viral proteins. This study also revealed that exposure of PRRSV to increased temperature was an efficient method of viral inactivation, but the mechanism of action still requires further investigation.

To investigate if the methods that seem the most suitable according to the in vitro screening assay described in this study are indeed good for preserving the immunogenicity of PRRSV inactivated vaccines, new experimental vaccines based on BEI and UV inactivation will be tested in animals.

Acknowledgements. The authors would like to thank C. Vanmaercke and C. Bracke for their highly appreciated and excellent technical assistance. We also want to thank J. Vandoorsselaere and D. Helderweirt (KATHO, Roeselare) for virus production and purification. L. Van Hoorebeke and P. Vanderniepen (Ghent University, Faculty of Science, Department of Subatomic and Radiation Physics) are acknowledged for advice and usage of their electron accelerator and technical assistance. This work was funded by the Agricultural Research Program from the Institute for the Promotion of Innovation by Science and Technology in Flanders (IWT-LO 040721). P.L. Delputte is a post-doctoral fellow of the Fund for Scientific Research Flanders (FWO).

\section{REFERENCES}

[1] Alderson T., The mechanism of formaldehydeinduced mutagenesis The monohydroxymethlyation reaction of formaldehyde with adenylic acid as the necessary and sufficient condition for the mediation of the mutagenic activity of formaldehyde, Mutat. Res. (1964) 106:77-85.

[2] Berhane Y., Berry J.D., Ranadheera C., Marszal P., Nicolas B., Yuan X., et al., Production and characterization of monoclonal antibodies against binary ethylenimine inactivated Nipah virus, J. Virol. Methods (2006) 132:59-68.

[3] Botner A., Nielsen J., Oleksiewicz M.B., Storgaard T., Heterologous challenge with porcine reproductive and respiratory syndrome (PRRS) vaccine virus: no evidence of reactivation of previous European-type PRRS virus infection, Vet. Microbiol. (1999) 68:187-195.

[4] Broo K., Wei J., Marshall D., Brown F., Smith T.J., Johnson J.E., et al., Viral capsid mobility: a dynamic conduit for inactivation, Proc. Natl. Acad. Sci. USA (2001) 98:2274-2277.

[5] Cancel-Tirado S.M., Evans R.B., Yoon K.J., Monoclonal antibody analysis of porcine reproductive and respiratory syndrome virus epitopes associated with antibody-dependent enhancement and neutralization of virus infection, Vet. Immunol. Immunopathol. (2004) 102:249-262.

[6] Cavanagh D., Nidovirales: a new order comprising Coronaviridae and Arteriviridae, Arch. Virol. (1997) 142:629-633.

[7] Chertova E., Crise B.J., Morcock D.R., Bess J.W. Jr, Henderson L.E., Lifson J.D., Sites, mechanism of action and lack of reversibility of primate lentivirus inactivation by preferential covalent modification of virion internal proteins, Curr. Mol. Med. (2003) 3:265-272.

[8] Cheung D.T., Nimni M.E., Mechanism of crosslinking of proteins by glutaraldehyde II. Reaction with monomeric and polymeric collagen, Connect. Tissue Res. (1982) 10:201-216.

[9] Christianson W.T., Choi C.S., Collins J.E., Molitor T.W., Morrison R.B., Joo H.S., Pathogenesis of porcine reproductive and respiratory syndrome 
virus infection in mid-gestation sows and fetuses, Can. J. Vet. Res. (1993) 57:262-268.

[10] Christopher-Hennings J., Nelson E.A., Nelson J.K., Benfield D.A., Effects of a modified-live virus vaccine against porcine reproductive and respiratory syndrome in boars, Am. J. Vet. Res. (1997) 58:40-45.

[11] Conzelmann K.K., Visser N., Van Woensel P., Thiel H.J., Molecular characterization of porcine reproductive and respiratory syndrome virus, a member of the arterivirus group, Virology (1993) 193:329-339.

[12] Cowley J.A., Dimmock C.M., Spann K.M., Walker P.J., Gill-associated virus of Penaeus monodon prawns: an invertebrate virus with ORF1a and ORF1b genes related to arteri- and coronaviruses, J. Gen. Virol. (2000) 81:1473-1484.

[13] Cranage M.P., McBride B.W., Rud E.W., The simian immunodeficiency virus transmembrane protein is poorly immunogenic in inactivated virus vaccine, Vaccine (1995) 13:895-900.

[14] Darnell M.E., Subbarao K., Feinstone S.M., Taylor D.R., Inactivation of the coronavirus that induces severe acute respiratory syndrome, SARSCoV, J. Virol. Methods (2004) 121:85-91.

[15] Delputte P.L., Meerts P., Costers S., Nauwynck H.J., Effect of virus-specific antibodies on attachment, internalization and infection of porcine reproductive and respiratory syndrome virus in primary macrophages, Vet. Immunol. Immunopathol. (2004) 102:179-188.

[16] Delputte P.L., Costers S., Nauwynck H.J., Analysis of porcine reproductive and respiratory syndrome virus attachment and internalization: distinctive roles for heparan sulphate and sialoadhesin, J. Gen. Virol. (2005) 86:1441-1445.

[17] Delputte P.L., Van Breedam W., Barbe F., Van Reeth K., Nauwynck H.J., IFN-alpha treatment enhances porcine Arterivirus infection of monocytes via upregulation of the porcine Arterivirus receptor sialoadhesin, J. Interferon Cytokine Res. (2007) 27:757-766.

[18] Dewey C.E., Wilson S., Buck P., Leyenaar J.K., The reproductive performance of sows after PRRS vaccination depends on stage of gestation, Prev. Vet. Med. (1999) 40:233-241.

[19] Di Trani L., Cordioli P., Falcone E., Lombardi G., Moreno A., Sala G., Tollis M., Standardization of an inactivated $\mathrm{H} 17 \mathrm{~N} 1$ avian influenza vaccine and efficacy against A/Chicken/Italy/13474/99 highpathogenicity virus infection, Avian Dis. (2003) 47: 1042-1046.

[20] Feron V.J., Til H.P., de Vrijer F., Woutersen R.A., Cassee F.R., van Bladeren P.J., Aldehydes: occurrence, carcinogenic potential, mechanism of action and risk assessment, Mutat. Res. (1991) 259:363-385.

[21] Fournier-Caruana J., Poirier B., Haond G., Jallet C., Fuchs F., Tordo N., Perrin P., Inactivated rabies vaccine control and release: use of an ELISA method, Biologicals (2003) 31:9-16.

[22] Fraenkel-Conrat H., Reaction of nucleic acid with formaldehyde, Biochim. Biophys. Acta (1954) 15:307-309.

[23] Gates K.S., Nooner T., Dutta S., Biologically relevant chemical reactions of N7-alkylguanine residues in DNA, Chem. Res. Toxicol. (2004) 17: 839-856.

[24] Grieb T., Forng R.Y., Brown R., Owolabi T., Maddox E., McBain A., et al., Effective use of gamma irradiation for pathogen inactivation of monoclonal antibody preparations, Biologicals (2002) 30:207-216.

[25] Grovit-Ferbas K., Hsu J.F., Ferbas J., Gudeman V., Chen I.S., Enhanced binding of antibodies to neutralization epitopes following thermal and chemical inactivation of human immunodeficiency virus type 1, J. Virol. (2000) 74:5802-5809.

[26] Knipe D.M., Howley P.M., Fields virology, 5th ed., Lippincott Williams \& Wilkins, 2006.

[27] Kuykendall J.R., Bogdanffy M.S., Efficiency of DNA-histone crosslinking induced by saturated and unsaturated aldehydes in vitro, Mutat. Res. (1992) 283:131-136.

[28] Labarque G., Van Gucht S., Van Reeth K., Nauwynck H., Pensaert M., Respiratory tract protection upon challenge of pigs vaccinated with attenuated porcine reproductive and respiratory syndrome virus vaccines, Vet. Microbiol. (2003) 95:187-197.

[29] Labarque G., Reeth K.V., Nauwynck H., Drexler C., Van Gucht S., Pensaert M., Impact of genetic diversity of European-type porcine reproductive and respiratory syndrome virus strains on vaccine efficacy, Vaccine (2004) 22:4183-4190.

[30] Labarque G.G., Nauwynck H.J., Van Reeth K., Pensaert M.B., Effect of cellular changes and onset of humoral immunity on the replication of porcine reproductive and respiratory syndrome virus in the lungs of pigs, J. Gen. Virol. (2000) 81:1327-1334.

[31] Lelie P.N., Reesink H.W., Lucas C.J., Inactivation of 12 viruses by heating steps applied during manufacture of a hepatitis B vaccine, J. Med. Virol. (1987) 23:297-301.

[32] Ma T.H., Harris M.M., Review of the genotoxicity of formaldehyde, Mutat. Res. (1988) 196: 37-59. 
[33] Maheshwari G., Jannat R., McCormick L., Hsu D., Thermal inactivation of adenovirus type 5, J. Virol. Methods (2004) 118:141-146.

[34] Meng X.J., Heterogeneity of porcine reproductive and respiratory syndrome virus: implications for current vaccine efficacy and future vaccine development, Vet. Microbiol. (2000) 74:309-329.

[35] Mengeling W.L., Lager K.M., Vorwald A.C., Temporal characterization of transplacental infection of porcine fetuses with porcine reproductive and respiratory syndrome virus, Am. J. Vet. Res. (1994) 55:1391-1398.

[36] Mengeling W.L., Lager K.M., Vorwald A.C., Safety and efficacy of vaccination of pregnant gilts against porcine reproductive and respiratory syndrome, Am. J. Vet. Res. (1999) 60:796-801.

[37] Meulenberg J.J., Hulst M.M., de Meijer E.J., Moonen P.L., den Besten A., de Kluyver E.P., et al., Lelystad virus, the causative agent of porcine epidemic abortion and respiratory syndrome (PEARS), is related to LDV and EAV, Virology (1993) 192:6-72.

[38] Meulenberg J.J., Petersen-den Besten A., De Kluyver E.P., Moormann R.J., Schaaper W.M., Wensvoort G., Characterization of proteins encoded by ORFs 2 to 7 of Lelystad virus, Virology (1995) 206:155-163.

[39] Meulenberg J.J., van Nieuwstadt A.P., van Essen-Zandbergen A., Langeveld J.P., Posttranslational processing and identification of a neutralization domain of the GP4 protein encoded by ORF4 of Lelystad virus, J. Virol. (1997) 71:6061-6067.

[40] Miller R.L., Plagemann P.G., Effect of ultraviolet light on mengovirus: formation of uracil dimers, instability and degradation of capsid, and covalent linkage of protein to viral RNA, J. Virol. (1974) 13:729-739.

[41] Misinzo G., Delputte P.L., Meerts P., Drexler C., Nauwynck H.J., Efficacy of an inactivated PRRSV vaccine: induction of virus-neutralizing antibodies and partial virological protection upon challenge, Adv. Exp. Med. Biol. (2006) 581:449-454.

[42] Mondal S.K., Neelima M., Seetha Rama Reddy K., Ananda Rao K., Srinivasan V.A., Validation of the inactivant binary ethylenimine for inactivating rabies virus for veterinary rabies vaccine production, Biologicals (2005) 33:185-189.

[43] Morgeaux S., Milne C., Daas A., Feasibility study to develop a common in vitro D antigen assay for inactivated poliomyelitis vaccines, Pharmeuropa Bio (2005) 2005:19-26.

[44] Neumann E.J., Kliebenstein J.B., Johnson C.D., Mabry J.W., Bush E.J., Seitzinger A.H., et al.,
Assessment of the economic impact of porcine reproductive and respiratory syndrome on swine production in the United States, J. Am. Vet. Med. Assoc. (2005) 227:385-392.

[45] Nielsen H.S., Oleksiewicz M.B., Forsberg R., Stadejek T., Botner A., Storgaard T., Reversion of a live porcine reproductive and respiratory syndrome virus vaccine investigated by parallel mutations, J. Gen. Virol. (2001) 82:1263-1272.

[46] Nielsen J., Botner A., Bille-Hansen V., Oleksiewicz M.B., Storgaard T., Experimental inoculation of late term pregnant sows with a field isolate of porcine reproductive and respiratory syndrome vaccine-derived virus, Vet. Microbiol. (2002) 84:1-13.

[47] Nielsen T.L., Nielsen J., Have P., Baekbo P., Hoff-Jorgensen R., Botner A., Examination of virus shedding in semen from vaccinated and from previously infected boars after experimental challenge with porcine reproductive and respiratory syndrome virus, Vet. Microbiol. (1997) 54:101-112.

[48] Ostrowski M., Galeota J.A., Jar A.M., Platt K.B., Osorio F.A., Lopez O.J., Identification of neutralizing and nonneutralizing epitopes in the porcine reproductive and respiratory syndrome virus GP5 ectodomain, J. Virol. (2002) 76:4241-4250.

[49] Permana P.A., Snapka R.M., Aldehyde-induced protein-DNA crosslinks disrupt specific stages of SV40 DNA replication, Carcinogenesis (1994) 15:1031-1036.

[50] Poon B., Safrit J.T., McClure H., Kitchen C., Hsu J.F., Gudeman V., et al., Induction of humoral immune responses following vaccination with envelope-containing, formaldehyde-treated, thermally inactivated human immunodeficiency virus type 1, J. Virol. (2005) 79:4927-4935.

[51] Prieto C., Suarez P., Bautista J.M., Sanchez R., Rillo S.M., Simarro I., et al., Semen changes in boars after experimental infection with porcine reproductive and respiratory syndrome (PRRS) virus, Theriogenology (1996) 45:383-395.

[52] Rodriguez M.J., Sarraseca J., Fominaya J., Cortes E., Sanz A., Casal J.I., Identification of an immunodominant epitope in the $\mathrm{C}$ terminus of glycoprotein 5 of porcine reproductive and respiratory syndrome virus, J. Gen. Virol. (2001) 82:995-999.

[53] Rooijakkers E.J., Uittenbogaard J.P., Groen J., Osterhaus A.D., Rabies vaccine potency control: comparison of ELISA systems for antigenicity testing, J. Virol. Methods (1996) 58:111-119.

[54] Rossio J.L., Esser M.T., Suryanarayana K., Schneider D.K., Bess J.W. Jr, Vasquez G.M., et al., Inactivation of human immunodeficiency virus type 1 infectivity with preservation of conformational and 
functional integrity of virion surface proteins, J. Virol. (1998) 72:7992-8001.

[55] Rossow K.D., Bautista E.M., Goyal S.M., Molitor T.W., Murtaugh M.P., Morrison R.B., et al., Experimental porcine reproductive and respiratory syndrome virus infection in one-, four-, and 10week-old pigs, J. Vet. Diagn. Invest. (1994) 6:3-12.

[56] Schlegel A., Immelmann A., Kempf C., Virus inactivation of plasma-derived proteins by pasteurization in the presence of guanidine hydrochloride, Transfusion (2001) 41:382-389.

[57] Sinha R.P., Hader D.P., UV-induced DNA damage and repair: a review, Photochem. Photobiol. Sci. (2002) 1:225-236.

[58] Subasinghe H.A., Loh P.C., Reovirus cytotoxicity: some properties of the UV-irradiated reovirus and its capsid proteins, Arch. Gesamte Virusforsch. (1972) 39:172-189.

[59] Terpstra C., Wensvoort G., Pol J.M., Experimental reproduction of porcine epidemic abortion and respiratory syndrome (mystery swine disease) by infection with Lelystad virus: Koch's postulates fulfilled, Vet. Q. (1991) 13:131-136.

[60] Van Gorp H., Van Breedam W., Delputte P.L., Nauwynck H.J., Sialoadhesin and CD163 join forces during entry of the porcine reproductive and respiratory syndrome virus, J. Gen. Virol. (2008) 89:2943-2953.

[61] Vanderheijden N., Delputte P.L., Favoreel H.W., Vandekerckhove J., Van Damme J., van Woensel P.A., Nauwynck H.J., Involvement of sialoadhesin in entry of porcine reproductive and respiratory syndrome virus into porcine alveolar macrophages, J. Virol. (2003) 77:8207-8215.

[62] Weismiller D.G., Sturman L.S., Buchmeier M.J., Fleming J.O., Holmes K.V., Monoclonal antibodies to the peplomer glycoprotein of coronavirus mouse hepatitis virus identify two subunits and detect a conformational change in the subunit released under mild alkaline conditions, J. Virol. (1990) 64:3051-3055.

[63] Wensvoort G., Terpstra C., Pol J.M., ter Laak E.A., Bloemraad M., de Kluyver E.P., et al., Mystery swine disease in The Netherlands: the isolation of Lelystad virus, Vet. Q. (1991) 13:121-130.

[64] Wieczorek-Krohmer M., Weiland F., Conzelmann K., Kohl D., Visser N., van Woensel P., et al., Porcine reproductive and respiratory syndrome virus (PRRSV): monoclonal antibodies detect common epitopes on two viral proteins of European and U.S. isolates, Vet. Microbiol. (1996) 51:257-266.

[65] Williams M.C., Gorelick R.J., Musier-Forsyth K., Specific zinc-finger architecture required for HIV-1 nucleocapsid protein's nucleic acid chaperone function, Proc. Natl. Acad. Sci. USA (2002) 99:8614-8619.

[66] Wissink E.H., van Wijk H.A., Kroese M.V., Weiland E., Meulenberg J.J., Rottier P.J., van Rijn P.A., The major envelope protein, GP5, of a European porcine reproductive and respiratory syndrome virus contains a neutralization epitope in its N-terminal ectodomain, J. Gen. Virol. (2003) 84:1535-1543.

[67] Wootton S.K., Yoo D., Homo-oligomerization of the porcine reproductive and respiratory syndrome virus nucleocapsid protein and the role of disulfide linkages, J. Virol. (2003) 77:4546-4557.

[68] Zuckermann F.A., Garcia E.A., Luque I.D., Christopher-Hennings J., Doster A., Brito M., Osorio F., Assessment of the efficacy of commercial porcine reproductive and respiratory syndrome virus (PRRSV) vaccines based on measurement of serologic response, frequency of gamma-IFN-producing cells and virological parameters of protection upon challenge, Vet. Microbiol. (2007) 123:69-85. 